Wright State University

CORE Scholar

\title{
The Forgotten Origins of the Ecumenical Movement in England: The Grindelwald Conferences, 1892-95
}

Christopher Oldstone-Moore

Wright State University - Main Campus, christopher.oldstone-moore@wright.edu

Follow this and additional works at: https://corescholar.libraries.wright.edu/history

Part of the History Commons

\section{Repository Citation}

Oldstone-Moore, C. (2001). The Forgotten Origins of the Ecumenical Movement in England: The Grindelwald Conferences, 1892-95. Church History: Studies in Christianity and Culture, 70 (1), 73-97. https://corescholar.libraries.wright.edu/history/250

This Article is brought to you for free and open access by the History at CORE Scholar. It has been accepted for inclusion in History Faculty Publications by an authorized administrator of CORE Scholar. For more information, please contact library-corescholar@wright.edu. 


\section{The Forgotten Origins of the Ecumenical Movement in England: The Grindelwald Conferences, 1892-95}

\section{Christopher Oldstone-MoOre}

Ruth Rouse, writing in A History of the Ecumenical Movement, made an extraordinary claim about the origins of modern ecumenism. She identified two factors in the 1890s that, in her words, "changed the course of Church history and made possible the modern ecumenical movement." ${ }^{\prime}$ One was the Student Christian Movement, established in 1895 by the American Methodist layman, John R. Mott. The other factor was the Grindelwald (Switzerland) Reunion Conferences, an assembly mostly of English church leaders organized by a Methodıst minister, Henry Lunn, between 1892 and 1895. Mott's movement is very well known to modern readers. The Grindelwald Conferences, by contrast, are utterly obscure in spite of Rouse's conclusion that they "began a new phase in the growth of the ecumenical ıdea."

Rouse's claim has never been thoroughly evaluated because there has been no study of the Grindelwald Conferences When historians have occasionally referred to the Grindelwald Conferences, it has usually been to recognize their connection with the establishment of the National Council of Evangelical Free Churches Yet even this connection has, for the same reason, been poorly understood. Indeed, Paul Phillips reverses cause and effect when he mistakenly described the Grindelwald Conferences as being organized "on behalf of the Free Church Council" 3 To address these misunderstandings, and to assess their historical significance, this article seeks to provide a clear picture of the origins, proceedings, and ramifications of the Grindelwald Conferences

1 Ruth Rouse, "Voluntary Movements and the Changing tecumenical Climate," in $A$ History of the Ecumentcal Movement, 1517-1948, eds Ruth Rouse and Stephen Charles Nelll (London SPCK, 1954), 338

2 Rouse, "Voluntary Movements and the Changing Ecumenical Climate," 340

3 Paul T Phillips, A Kingdom on Earth Anglo-American Sir ial Christianty, 1880-1940 (Unuversity Park, Pa Penn State University Press, 1996), '82

Christopher Oldstone-Moore is an adjunct th the department of history at Wittenberg University in Springfield, Ohoo

(C) 2001, The American Society of Church History

Church History 701 (March 2001) 
It is helpful to clarify what the Conferences were and what they were not. They were the first formal (not official) discussions between British church leaders about reuniting British Protestantism. Lunn's journal, The Review of the Churches (first series, 1891-96; second series, 1924-30) was likewise the first British periodical devoted to Christian union. Their mere existence made news, as was intended, and $W T$. Stead in particular helped to publicize them on both sides of the Atlantic in his Revuew of Revtews ${ }^{4}$ Rouse has argued that the Grindelwald Conferences were important because they first expressed the conviction that "the Churches as such must face their differences together through their official representatives," rather than through nondenominational bodies or ad hoc meetings of interested church leaders, such as the Grindelwald Conferences themselves. This was the idea, Rouse noted, that animated the Faith and Order Movement. ${ }^{5}$ Yet Rouse also admits that it is difficult to draw a direct link between the two movements. A still more fundamental problem is that Rouse's summation of the outcome of Grindelwald is misleading. Though it is true that the idea of an official, representative conference was briefly discussed at Grindelwald, the participants did not generally embrace it. It cannot be said, therefore, that this idea lınks Grindelwald to the Falth and Order Movement.

A close study of the Grindelwald Conferences leads to the conclusion that they were, in an ecumenical sense, truly ahead of their time. They were a dead end that anticipated rather than precipitated the ecumenical movement as it later developed As one partıcıpant wrote only a few years afterwards, "the movement for the reunion of Christendom, it is not unfair to say, awakened no popular enthusiasm; it is today almost forgotten by the public." The fact that the Grindelwald Conferences were not the direct precursor of the Faith and Order Movement does not mean, however, that they did not have important historical consequences. This study will attempt to elaborate two such consequences. First, the Grindelwald Conferences were a critical stage in the establishment of the National Councl of Evangelical Free Churches, which, in the words of D. W. Bebbington, became "one the most significant pressure groups of Edwardian England" and the progenitor of subsequent Free Church federal organizations to the

4 Articles and pictures about the Grindelwald Conferences in the American edition of the Review of Revtews can be found in volumes 6 (1892) 310-17, 452-56 and 8 (1893) $446-49$

5 Rouse, "Voluntary Movements and the Changing Ecumencal Climate," 340

6 Dugald Macfadyen, Alexander Mackennal, B A, D D Life and Letters (London J Clarke, 1905), 232 
present day. ${ }^{7}$ Second, as the first English forum for the debate on church union, the Conferences helped articulate and publicize the primary issues separating the churches in that country. In sum, the Conferences represented the first awkward steps in English reunion endeavors that have continued fitfully to the present. Indeed, as observers of the recent arguments over the Lutheran-Episcopal Concordat in the United States may attest, the terms of ecumenical debate in Anglo-American Protestantism remain remarkably unchanged in the century since those first discussions in Swityerland.

\section{The Inspiration for Reunion Conferences}

The story of the Grindelwald Conferences begins with Henry Simpson Lunn, a man who succeeded in combining many careers in a single lifetime: Methodist minister, medical doctır, businessman, and politician. He became best known in Britain as the founder in 1902 of the Public Schools Alpine Sport Club and in 1909 of a successful travel agency (which still exists under the name LunnPoly) that pioneered ski resort package tours to Switzerland. This innovative business evolved from his experience as the organizer of the Grindelwald Conferences. He was knighted for his religious and business accomplishments in 1910. Lunn also had two notable sons. His second son was the essayıst, biographer, and novelist who took the pen name Hugh Kingsmill; his oldest son, Arnold, was alio an noted essayist, but was best known as the inventor of modern slalom sking and as the man responsible for making skiing an Olympic sport. ${ }^{8}$

Lunr was born in 1859, the son of a Lincolnshire merchant. As a young man he built up his own mail-order busine'ss selling equipment for the new sport of lawn tennis. He earned enough to pay for his university education before selling out to his father and entering Headingley College, the Methodist seminary in Leeds. After two

7 D W Bebbington. The Nonconformist Conscuence Chapel ard Politics, $1870-1914$ (London George Allen and Unwin, 1982), 61 "Free Churches" was a term adopted in the 1890 s to refer to Noncontormist denominations in Engl ${ }^{\prime}$ nd and Wales (where the Church of England was still established by law) The Free Church Congress, which first met in 1892 and which later evolved into the National (ouncil of Evangelical Free Chuiches, included Methodists of their several denomisitions, Congregationalists, Baptists, Presbyterians, and Quakers Untarians and the Salvation Army were excluded In 1919 the Baptist J H Shakespeare led in establishing the Federal Council of the livangelical Free Churches, which was made up of representatives appointed by the denominations rather than the local councits In 1940 the National Council and Federal Council were merged to form the Free Church $\mathrm{C}_{6}$ uncil

8 T F Burns, "Sir Arnold Henry Moore Lunn," in Dh th Hury of National Bugraphy 1971-1980, eds Lord Blake and (S Nicholls (Oxford Oxi ord University Piess, 1986), 522-23 It would be fair to conclude that Olympic slalsm sking was one of the unplanned results of the Cirindelwald Conferences 
years at Leeds, he crossed the Irish Sea to complete a bachelor's degree and then a master's degree in theology and medicine at Trinity College, Dublin. He was ordained in the Methodist ministry in 1886 and was awarded his medical doctorate in 1887. In the same year, he married Ethel Moore, a daughter of an Anglican rector in County Cork. At Trinity College, Lunn combined an admiration for Anglicanism with his steadfastness to Methodism and also mixed political activism with religious commitment. Both of these dualities were quite important in the evolution of his career. He joined the Contemporary Club, an exclusive debating society in Dublin, served as a correspondent for the progressive Methodist Times, and actively promoted the Liberal Party's policy of Home Rule (local self-government) for Ireland ${ }^{9}$

Lunn was one of many young, educated Methodists inspired by Hugh Price Hughes's "Forward Movement" in the 1880s and 1890s. Hughes, the Welsh-born leader of progressive Methodism, sought to transform the Wesleyan Connexion, as it was officially still called in the 1880s, into the Methodist Church. This new Methodist Church was to be evangelical but not sectarian. It was also to be independent yet also, like the established Church of England, serve as the conscience of the state and take on an institutional responsibility for the spiritual and social well-being of the nation as a whole. Through the Methodist Times and his showpiece West London Mission, Hughes sought to inspire younger Methodists to bulld a more democratic and militant church that could evangelize the cities and promote social and moral reforms such as temperance, the reduction of sexual vice and gambling, labor and women's rights, international peace, home rule in Ireland, and the expansion of public education, housing, and employment. ${ }^{10}$ Although conservative Methodists prevented him from attaining high office for some time, Hughes had become by 1890 the preeminent figure of Wesleyan Methodism. ${ }^{11}$ Henry Lunn, following his hero's lead, threw himself into the campaign for Irish home rule, while also preparing to become a medical missionary in India.

After a disappointing and illness-plagued year in India, Lunn became Hughes's assistant at the West London Mission and a close personal friend. At this time Lunn was not yet a committed ecu-

9 Lunn was so effective as a stump speaker that Charles Stewart Parnell, leader of the Insh Parhamentary Party, offered him a seat in Parliament See Henry S Lunn, Chapters From My Life (London Cassell and Co, 1918), 43

10 Christopher Oldstone-Moore, Hugh Price Hughes Founder of a New Methodism. Consctence of a New Nonconformity (Cardiff University of Wales Press, 1999)

11 W T Stead, "Hugh Price Hughes and His Work," Revreve of Rezume (N Y) 4, no 2 (October 1891) 279-84 
menist. His first campaign for reform was directed at foreign mission policy. With Hughes's encouragement, he published in 1889 in the Methodist Times a series of stinging critiques of I'rotestant missions in India, blaming their relative failure on the high pay and aloof superiority of the missionaries. The Methodist missionaries in India and their conservative supporters at home responded by demanding a retraction and apology or Hughes's and Lunn's resignations from the ministry. After a partial retraction, Lunn was obliged in 1890 to resign from the West London Mission and find employment outside Methodism as chaplain of the Regent Street Polytechnic in London. This crisis led to Lunn's ecumenical activities in two ways. It dislodged him from his denominational affiliation and it obliged him to think of new ways to promote Christian and social reforms.

Although Lunn was no longer employed by Hughes's mission, he remained very close to his Methodist friends and, for this purpose, moved his household to Endsleigh Gardens in Bloomsbury, around the corner from Hughes and next door to Percy Bunting, the treasurer of the West London Mission and editor of the intluential Contemporary Review. This friendship was crucial, for Hugh's and Bunting were then embarking on a new campaign for greater unity among English Nonconformists.

Before the last quarter of the nineteenth century, Methodistsparticularly the largest and most conservative denomination to which Hughes, Bunting, and Lunn belonged, the Wesleyan Methodistshad held aloof from other Nonconformist bodies. Many Wesleyans in the early nineteenth century followed Wesley's 'xample of remaining in communion with the Church of England. In the latter part of the century, however, there were several factors that drew Wesleyans towards other Nonconformists. First was the fact that most Anglicans considered Methodists to be dissenters, and Methodists suffered the same legal and social disabilities as other Nonconformists. Although most legal disabilities were removed by the $1880 \mathrm{~s}$, the social disadvantages of non-Anglicans persisted, disadvantages that were even more keenly felt as Nonconformists prospered later in the century A second and equally important reason for a grou ing sense of Nonconformist common identity was the contrast between the evangelical traditions of Methodism and Nonconformity grenerally, on the one hand, and the increasing ritualism and tendency to Catholicism in the Church of England on the other In the middle of the nuneteenth century, the most important renewing force in the Church of England had been the Oxford Movement, whereas for other Protestant groups it had been the remarkable revivals of the $1860 \mathrm{~s}$. Ind again in the $1870 \mathrm{~s}$ in the wake of Dwight Moody's English tours. 
It might be supposed that the antidote to this divergence of Nonconformity and Anglicanism was to be found in the emergence of Christian Socralism, along with its associated broad-church ecclesiology. Indeed, as Paul T. Phillips has put it, "the theme of unity was an enduring one in the history of Social Christianity."12 Nonconformists and Anglicans alike were inspired by the idea, advocated most memorably by Arnold, Stanley, Maurice, and Fremantle, of a broad, national church that would unite the nation and heal social ills. Surprisingly, however, Social Christianity actually divided Nonconformists from Anglicans still more because of their contrasting versions of Social Christianity As articulated by Hugh Price Hughes or the Baptist leader John Clifford, Nonconformist Social Christianity took its cue from the antislavery and temperance campaigns of old: it sought social redemption in evangelical enthusiasm, voluntaristic political agitation, and a rhetoric of egalitarian democracy. Anglicans, by contrast, whether following the broad-church tradition of the Christian Social Union or the Anglo-Catholic mold of St Matthew's Guild, still clung steadfastly to the ideal and apparatus of the established church.

This divergence of Nonconformity and Anglicanism had its political dimension as well. In this respect again, the shift of Methodist allegiance was the critical change. As they sought to be more influential and effective in social and political affairs, Methodists increasingly found themselves, like Lunn in his campaign for Irish Home Rule, in political union with Gladstonian Liberalism and its Nonconformist supporters. Most Methodists supported liberal policies of Irish Home Rule, the disestablishment of Welsh Anglicanism, temperance, and especially public, nonsectarian education.

The debate over education most perfectly embodied the social and political convergence of Nonconformity and was the occasion for the first call for a structured Nonconformist unity in the 1890s. In 1888, a Royal Commission appointed by the conservative government of Lord Salisbury reported in favor of levying local rates to support voluntary (that is to say private) schools Most of these schools were administered by the established church. A debate that had convulsed the nation in 1870 was renewed, and Nonconformists rose in opposition, supported more vigorously than before by Methodists. Hugh Price Hughes wrote in his own newspaper and in Bunting's Contemporary Revlew to denounce the report, and he joined forces with the prominent Congregationalist minister, Guinness Rogers, among oth-

12 Phillips, A Kingdom on Earth, 162 
ers, in founding the National Education Association to advocate expansion of a nonsectarian school board system. It was at this point that Hughes and Percy Bunting convinced Guinness Rogers to declare on the front page of the Methodist Times that it was time to call a Free Church Congress. "The mere demonstration of the unity of Evangelical denominations," Rogers wrote, "would exercise a power which is not easy to measure." "It would provide, Roges s believed, a counterpoise to the Anglican zeal for preserving the Estıblishment, especially in education. Reflecting some years later on this time, Congregationalist minister Sylvester Horne wrote that "the Free Churches came together under the shadow of a great common peril. Everywhere it was felt and recognised that the maintenance of the sturdy Protestant character of English life and worship rested mainly upon them." 14 No doubt Horne was over-dramatizıng, but his words do reflect the main emotional impulse for unity.

Later in 1890, Hughes, Rogers, W. T. Stead, and John Clifford led the campaign to oust the leader of the Irish Party in Parliament, Charles Stewart Parnell, for adultery. To these veterans of the social purity campaign against prostitution and vice (though erstwhle supporters of Parnell), no unrepentant adulterer was to be accepted in political leadership. The subsequent fall of Parnell was further proof of the political potential of a united Nonconformity. Only a few months after the Parnell crisis, in the spring of 1891, a group of Nonconformist leaders gathered in Percy Bunting's home and resolved to hold the first Free Church Congress the following year in Manchester. Alexander Mackennal, minister of Bowdon Downs Congregationalist Church in Manchester, was made secretary and chief organizer of the first congress. In the summer of 1891, a London Nonconformist Council was established, and a curcular signed by Hughes, Clifford, and others was sent to all Free Church ministers calling for a union of Evangelical churches in each town or district "for mutual aid and encouragement, for the guidance of united counsel, and of the cooperation and power of united action in their social ministries of redeeming love." 15

Drawing inspiration from the ecumenical leadership of his friends, Lunn sought to extend it by attempting to bridge the forbidding gap between Nonconformity and Anglicanısm. He' and Bunting struck

13 Methodist Times, 20 February 1890, 173-74

$14 \mathrm{C}$ Sylvester Horne, A Popular History of the Free Churchen (London Congregational Un.on, 1926), 424

15 Macfadyen, Alexamder Mackennal, 491 See also $\mathrm{D} W$ Bebbington. The Noncunformist Corsctence, 63 
upon the concept for a new journal modeled on Stead's Review of Reviews that would facilitate discussion among all Protestant denominations and prepare the way for eventual reunion. ${ }^{16}$ The first issue of The Review of the Churches appeared in October 1891 with Lunn as general editor and Bunting as the Methodist editor. Lunn recruited Alexander Mackennal as Congregationalist editor, John Clifford for the Baptısts, Donald Fraser for the Presbyterians, and Frederic Farrar, Archdeacon of Westminster, for the Church of England. For his part, Hugh Price Hughes responded to his protégé's initiatıve by quickly embracing a broader ecumenism. Hughes and Lunn shared a very clear perspective that may be summarized as follows: a militant church, like any military force, succeeds best when the forces are united and augmented. In the first number of the Rentew, Hughes decried "the loss of hope, esprit de corps, enthusiasm, and expectation of victory on the part of Christians" and lamented that "the great majority of the European races are at this moment outside the Christian Church, and the overwhelming majority of the human race are heathen." He concluded from these facts that "we ought to be prepared, for the sake of union, to sacrifice everything except loyalty to Christ." ${ }^{17}$ As these words indicate, ecumenism, as Hughes viewed it, was not so much a theological issue as it was an evangelical and sociological one. Indeed, it is fair to say that Hughes and Lunn hoped that evangelical and sociological considerations would supersede theological and ecclesiological differences in bringing Christians together. This conception anticipated the thinking of that other notable Methodist, John R. Mott, as he prepared the World Missionary Conference of 1910, although Mott was apparently unaware of Hughes's and Lunn's writings ${ }^{18}$

The idea of holding reunion conferences of church leaders evolved in Lunn's mind during 1891 and 1892. As chaplain of Regent Street Polytechnic, he organized student excursions to Norway. In a conversation with a Norwegian ship captain and Hughes's wife, Katherine

16 Lunn, Chapters, 142

17 Reverw of the Churches 1, no 1 (October 1891) 14

18 Though Mott seems to have known little about Hughes, there is a remarkable simularity of view Hughes's statement of 1891 might be compared with a passage from Mott's Decisize Hour of Christian Missions (1910), where he articulated his belief that the imperative of world evangelism would dissolve doctrinal distinctions "Who can measure the federative and unifying influence of foreign missions? No problem less colossal and less bafflingly difficult will so reveal to the Christians of today the sinfulness of their divisions and so convince them of the necessity of concerted effort, as actually to draw them together in answer to the intercession of their common and divine Lord " Quoted in C Howard Hopkins, John R Mott, 1865-1955 (Grand Rapids, Mich Willaam B Eerdmans, 1979), 363 
Price Hughes, ${ }^{19}$ it was suggested that holiday retreats in Norway would greatly benefit overworked clergymen Later it occurred to Lunn that this might also be a suitable way to promote Christian unity. ${ }^{20}$ He invited a number of ministers on a trip to Norway in January 1892. Hughes and several other leading Nonconformist ministers agreed to go, but when one and then another ship booked to carry this party sank before the departure date, Lunn settled instead on Switzerland as a safer and more suitable destination. He arranged for parties of clergymen and families to travel to Grindelwald to enjoy the serene majesty of the Alps and a program of lectures and discussions on a variety of religious subjects. The central events in that summer of 1892 were a day-long "Reunion Conference" in July and a week-long conference in September. It was a bold idea; Lunn himself marveled at the audacity of inviting every Anglican bishop and a host of other clerical luminaries to join hım in Switzerland.

Lunn's enterprise, however, was not so brazin as it might at first appear. Although widening, the gap between Anglicanism and Nonconformity did not appear entrrely unbridgeable. A long-standıng tradition of Protestant cooperation exemplified by nondenominational organizations, such as the Evangelical Aliance, the British and Foreign Bible Society, the Religious Tract Societ, and the YMCA, was not entirely lost and was renewed in the $1870 \mathrm{~s}$ and $1880 \mathrm{~s}$ when scholars from throughout British Protestantism were included in the preparation of the Revised Version of the Bible ${ }^{21}$ Although the final decades of the century were marked by efforts to build denominational organizations rather than nondenominational ones, these new efforts also contributed to an atmosphere of ecumenism In 1867, the Anglican Communion held its first worldwide conterence of bishops at Lambeth Palace at the request of Canadian bishops who wanted to influence affairs in the Anglican Province of South Africa Other English churches followed this lead. The General Presbyterian Alliance first met in 1877 The first worldwide Methodist Ecumenical

19 Katherine Price Hughes joined her husband as a leader of Forward Movement Methodism, especially as an advocate of women's role in the church and as the superintendant of a sisterhood of social workers at the West London Mission, about which she delivered addresses at Grindelwald She also served on the executive committee of the Ladies' Liberal Federation After her husband's death in 1902, she remaned at the West London Mission and was in 1911 the first woman delegate to address the Wesleyan Methodist Conference See Katherme Price Hughes, The Stori; of My Lif" (London Epworth, 1945) See also Oldstone-Moore. Hugh Pric' Hughe's

20 Henry Lunn, "A 'Reunion' Trip to Norway," Revucu of the' Chundes 1, no 2 (November 1891) 143

21 Ernest Payne,"Toleration and Establishment," in From Unuformity to Unity 1662-1962, eds Geoffrey F Nuttall and Owen Chadwick (I.ondon GPCK, 1962), 281 
Conference gathered in 1881, the International Congregational Councll in 1891, and the Baptist World Alliance in $1905 .{ }^{22}$ The idea of uniting separate denominations had not made much headway by 1892, though it was perhaps the next logical step

This next step was indeed anticipated by the Lambeth Conference of 1888. There the world's Anglican bishops approved the so-called "Chicago-Lambeth Quadrilateral" that had been adopted by the American Episcopal Church in 1886. The Quadrilateral was conceived by American clergyman Willam Reed Huntington in 1870 to faclitate ecumenical discussions between Anglicans and other churches by articulating the four essential elements of the Anglican idea of the church. $^{23}$ The Lambeth formulation was

1. The Holy Scriptures of the Old and New Testaments as "containing all things necessary to salvation" and as being the rule and ultimate standard of faith.

2 The Apostles' Creed as the baptismal symbol, and the Nicene Creed as the sufficient statement of the Christian fath

3 The two sacraments ordaned by Christ himself-baptism and the Lord's Supper-ministered with unfailing use of Christ's words of institution and of the elements ordaned by him.

4 The historic episcopate, locally adapted in the methods of its administration to the varying needs of the nations and peoples of God into the unity of his church ${ }^{24}$

The Quadrilateral was an important watershed in Anglo-American ecumenical history, but in England it was a watershed whose waters initially sank underground It seemed much less relevant in England, where the Anglicans dominated, than in the United States, where Anglicans were a small minority. At Grindelwald, however, the Lambeth Quadrilateral became what it was meant to be-a starting point for discussing the union of Protestantism. By Lunn's account, Nonconformists knew almost nothing of the Quadrilateral untıl it was explained in a paper delivered at Grindelwald by J. Harford Battersby, a founder of the Keswick Convention of evangelical Anglicans. Hugh Price Hughes, for one, was impressed by "the wonderfully liberal proposals of the Bishops of the Lambeth Conference "25

22 Payne, "Toleration and Establishment," 283-84

23 J Robert Wright, "Heritage and Vision The Chicago-Lambeth Quadrilateral," Anglcan Theological Renew, Supplementary Series, No 10 (March 1988) 9-10

24 For the text of the Chicago and Lambeth versions of the Quadrilateral, see Anglican Theological Rezurw, Supplementary Series, No 10 (March 1988) vil-1x For the text of the Chicago version of the Quadrilateral, see Book of Common Prayer according to the use of the Episcopal Church (New York Church Hymnal Corporation, 1979), 876-78

25 Henry S Lunn, "The Church and the World," Revicw of the Churches (new series) 7, no 3 (July 1930) 334 
The Quadrilateral became the focus of discussions during the first Grindelwald Reunion Conferences in the summer of 1892, and though the conferences thereafter pursued other themes, it remained a touchstone, especially in discussions about the church and its governance. Anglican and Free Church leaders agreed that the fourth clause was the critical one. Baptists, Congregationalists, and Presbyterrans generally viewed the episcopate, and especially the concept of apostolic succession implied in the term "historic episcopate," as unacceptable. As leader of the Methodist contingent, Hughes stood where Methodists had historically stood, in the middle, arguing for the acceptance of the historic episcopate on suitable terms.

\section{The First Year: High Expectiations}

The Grindelwald Conferences were held on four successive summers from 1892 to 1895 , and in that time the positions taken on key issues such as the apostolic succession never really changed. Initial enthusiasm about finding common ground gradually dissolved into a more sober, less expectant mood. The significance of the conferences is not to be found in any new theological breakthrough. The conferences were in any case unofficial meetings. Rather, their significance was in promoting new clarity and understanding, even if it was to understand just how far away Christian unity really was. An important topic of discussion was, therefore, what intermediary steps might be taken towards eventual union The conferences ended for reasons of both success and fallure success in clarifying the problems to be faced and failure to find ready solutions to those problems Grindelwald was a first, halting step in what has proven to be a very long process indeed.

The question of the episcopacy dominated the first round of discussions in July 1892 Prebendary Hay (William Hay MacDowall Hunter) Aitken, the main Anglican speaker, contended that the acceptance of the episcopacy would be a reasonable concession for Nonconformists, especially when it was understood that the adoption of "historic episcopacy" did not imply the acceptance of the doctrine of apostolic succession or an exalted conception of a bishop. ${ }^{26}$ Congregational and Baptist participants were cool to these overtures. Alexander Mackennal, the Congregationalist ectitor for the Revuew of the Churches who was at the time making preparations for the first Free Church Congress, believed that the fourth clause of the Quadrilateral veiled the attempt of the high-church faction in Anglicanism to

26 Rernew of the Churches 2, no 5 (August 1892) 329-32 
conserve the dubious doctrine of the apostolic succession. ${ }^{27}$ Richard Glover, a Baptist, rejected the necessity of bishops altogether, maintaining that "in the strict sense of the word only God could ordain a man." ${ }^{28}$ Even the outspoken broad-churchman, Canon William Henry Fremantle of Rupon, complained that the Quadrilateral made the episcopacy too prominent in the doctrine of the church. Robert F. Horton, another prominent Congregationalist, wanted to abandon discussion of bishops altogether. His view was that they "ought not to attempt even to bring about artificial and external union, but the object of the conference should be to make each one of them so appreciative of the views and purposes of all the rest, that it would be with the greatest difficulty that each stuck to his own denomination after going back."

Lunn made certain, however, that the issue of the Quadrilateral and bishops remained the focus of debate. He did not take a prominent role in the conferences himself, but gave pride of place to Hugh Price Hughes and his colleague Percy Bunting, who attempted to establish a third position between the Anglicans and the dissenters. Lunn usually scheduled Hughes to be the final speaker of each conference in order to have the last word. In the first conference Hughes emphasized not the method of union so much as its urgency. Spiritual unity without ecclesiastical union was of little moment, he argued, and the political and evangelical effectiveness of the church depended on a visible union. An effectıve, visible church lıkewise implied strong leadership. Accordingly, Hughes declared himself in favor of the epıscopacy to govern a united church: "As far as I know Episcopacy existed in the Christian Church, at least from the time of the Apostle John, and I have not the least doubt, from a careful study of this particular question, that the episcopal system is much more effectual for aggressive purposes than any other. The authority of some representative minister, duly and properly chosen, who has the right of initiative, is of immense advantage in carrying on a war into the enemy's country." ${ }^{29}$ A new, united church would incorporate both the evangelicalism of Nonconformity and the institutional effectiveness of the Church of England Percy Bunting predicted that under Hughes's leadership, Methodists would soon have bishops of their own, and he challenged Anglicans to accept them. ${ }^{30}$ By Lunn's account, Hughes's embrace of the episcopacy surprised and impressed

27 Reviez of the Churches 2, no 5 (August 1892) 332

28 Rezuew of the Churches 2, no 6 (September 1892) 370

29 Revew of the Churclues 2, no 6 (September 1892) 375

30 Revule of the Churches 2, no 5 (August 1892) 334 
the Anglican contingent. ${ }^{31}$ Other Nonconformists, not surprisingly, were much less enthusiastic.

At the week-long conference in September of 1892, the Anglicans were represented by the Bishop of Worcester, John James Stewart Perowne, along with Canon Fremantle, Professor George Thomas Stokes of Dublin University, and Professor John James Lias of Cambridge University. The Congregationalist deputation was led again by Alexander Mackennal, but now included one of their rising stars, Charle's A. Berry, who shared the doubts of his colleagues regarding the Anglican position on bishops, but who warmed to the idea of the institutional union of British Protestantism. Baptists were led by C F. Aked, while the Methodist contingent of Lunn, Hughes, and Buntıng was augmented by another Hughes ally, Bowman Stephenson, an ex-president of the Wesleyan Methodist Conference

Bishop Perowne, leading off the discussions, adopted an even more conciliatory stand than Aitken had taken in luly The bishop disavowed the theory of apostolic succession and expressed his opinion that it was unnecessary for Nonconformists to be reordained if they united with the Church of England. Later in the discussions, Professor Lias supported the bishop in attesting history to be against the doctrine of apostolic succession and in favor of permitting churches as well as bishops to consecrate new bishops and ordain ministers. Charles Berry was the first to respond to these Anglican overtures, and he rehearsed the objections of Baptists and Congregationalists in the first conference. He especially feared that the high-church interpretation of episcopacy would violate the convictions of Nonconformists. He suggested that the first step should be establishing the principle of equality among the churches. Their present need was "a recognition of each other's rights in the kingdom and of each other's churches as parts of the kingdom." ${ }^{12}$ Stephenson agreed that "mutual recognition of churchmanship" was the neces iary first step, but he was more hopeful about union. He, like Hughes, favored an episcopal form of government and believed that Wesley had also. He even thought it was time to convene direct discussions between Anglicans and Methodists. Hughes repeated his plea for other Nonconformists to accept the episcopacy. He insisted they would have nothing to fear even from the high-church faction so long as ministers and bishops were duly elected. ${ }^{33}$

31 Lunn, Chapters, 170

32 Revew of the Churches 3, no 1 (October 1892) 43

33 Renew of the Churches 3, no 1 (October 1892) 52 
On the Sunday following the discussions, Bishop Perowne presided over a communion service in the local Zwinglian church for the conference partıcipants. Angry letters from Anglicans who disapproved of the bishop's action appeared in the Times and other journals. Although most observers, including the bishops, did not see any offense in Worcester's action, they were little impressed by the tendency of the Grindelwald discussions. The Times warned that "a large and important section of [the Church of England] are by no means willing to receive back the Nonconformist wanderers on terms which they could be brought to accept." ${ }^{34}$ In a ridiculing tone, the Spectator agreed and reprimanded Bishop Perowne for misleading his listeners with regard to the position of the established church. ${ }^{35}$ Canon Charles Edward Hammond, a spokesman of the high-church Anglicans, traveled to Grindelwald the following July in order to deny the right of Nonconformist bodies even to consider themselves churches and to maintain that the return of Nonconformists to the Establishment was the only method of reunion

\section{Defining the Church and Pursuing Nonconformist Unity}

Subsequent discussions and events were to indicate that this reaction from high-church Anglicans had three important effects. First, it forced the Grindelwald discussions to retreat from hopes for organic union of Protestantism; second, it inspired many partıcipants to grapple with the definition of the church, and third, it helped to cement Nonconformist solidarity. The conferences of 1893 were held in Lucerne because a fire had damaged much of Grindelwald In July, participants were subjected to another sort of fire, politely hearing Canon Hammond declare the utter impossibility even of Anglican recognition of, much less union with, Nonconformists. Lunn expressed disappointment in the July meetings, not only because of Hammond's position, but because the sessions thereafter retreated from the earlier focus on ecclesiastical union. This was rectified somewhat in the September meetıng when the challenge from the highchurch faction seems to have directed attention to the definition of the church. Hammond had defined the Church of England as the only true church in England. Anglican speakers in the September meetıng took less extreme positions, though none thought a union between Anglicans and Nonconformists was practical in the near term. Prebendary Hamner William Webb-Peploe, consistent with the evangelical tradition of the Keswick movement, thought that spiritual unity

34 Quoted in Revtew of the Churches 3, no 2 (October 1892) 56.

35 Spectator, 69, no 3351 (17 September 1892), 375 
and practical cooperation were the ends they should seek, rather than ecclesiastical union, but other speakers returned to the troublesome issue of pastoral authority. Professor John Jame's Lias of Cambridge, after describing the severe criticism he faced in Cambridge for his statements the previous year, wished to affirm his belief in the 1mportance of episcopacy to the church, but he still thought that if bishops were made less powerful and congregations more independent, the system of episcopacy could be accepted as a basis of unity Philip Vernon Smith, Chancellor of the Diocese of Manchester, argued that Nonconformists did not have a clear ecclesiology comparable to the Church of England's. He thought Nonconformists should tirst define their concept of church in the same manner that the Lambeth Quadrilateral had for Anglicans.

Congregationalists Charles Berry and Alexander Mackennal tended to agree with Smith, though Mackennal thought Nonconformists had practically done so already. He noted that Nonconformists in the last half of the nineteenth century had come to recognize the wider communal responsibilities of the church and to accept the concept of a visible church organized for the good of the whole community. Mackennal was persuaded that because the church was defined by this communal responsibility, unity must therefore begin in the local communities and among like-minded denominations and expand from there. Berry, however, thought the Free Churches as a whole could do more to improve their ecclesiology. He viewed the problem of defining the church to be their central theological problem; they must learn to stand on their own by elaborating and asserting their ecclesiastical ideas in contrast to Anglicans and Catholics, whom he described as the true schismatics because of their false claims about the church and the priesthood. Non-Anglicans, he argued, should stop referring to themselves by the negative label of Nonconformist and assume equality with the Church of England He told the meeting that "[ have publicly repudiated the name of Protestant, as I have also repudiated that of Dissenter and Nonconformist. I, too, am a Catholic Churchman." 36

For the Methodists, Percy Bunting took a similar line, arguing that what was most needed for ecumenical progress was "a thorough mutual recognition of the Christian position of one another's churches--not merely the recognition of the individual. ${ }^{137}$ Although gradually moving towards Berry's line of thinking, Hugh I'rice Hughes was still thinking more about unity than equality. He emphasized the imper-

36 Review of the Churches 4, no 6 (September 1893) 364

37 Review of the Churches 4, no 6 (September 1893) 356 
ative of Christian union in terms of a simple, functional definition of the church "The Church of God," he explained, "1s the living army by which God intends, providentially and mainly, to establish the kingdom of God in all lands.... You cannot get the self-sacrifice, the devotion, the enthusiasm, and patient perseverance necessary to success except from Christians, and therefore I am bound to regard the church as a visible cooperation, as a means to an end and not an end in itself. ${ }^{38}$ Hughes was mindful that several speakers such as WebbPeploe had favored practical cooperation in social or evangelical activities rather than an organic union. Hughes wanted to emphasize his view that the dichotomy between organic union and practical cooperation was a false one; organic union was itself supremely practical - the very foundation for effective cooperation. Nevertheless, he was prepared to admit that union must proceed stepwise and might naturally begin with the reunion of the Methodist bodies (for which he had long been campaigning) and between the various Nonconformist denominations.

Lunn was pleased by the tone of the second 1893 Conference and by the increased attention in Britain to church reunion. He had a resolution passed calling for the declaration of an annual "Reunion Sunday" and followed up by writing to clergymen across the country asking for annual sermons and prayers for unity on every Whit-Sunday. In May 1894 he produced a long list of clergy who had given a positive response and proudly reported that the Archbishop of Canterbury had recommended to his clergy the use of the prayer for unity from the Ascension service. ${ }^{39}$

The Grindelwald conferences of 1893 proved to be a turning point in the course of Nonconformist unity. The historlan D. W. Bebbington has noted that Charles Berry originated the theology of "Free Churchmanship" that shaped and guided the evolution of the Evangelical Council of Free Churches. ${ }^{40}$ Grindelwald gave shape and impetus to this theology. Though Berry's concepts of churchmanship can be traced to the influence of the great Congregationalist divine, R. W. Dale, they now came to fruition. ${ }^{41}$ The primary promoter of this theology besides Berry himself was Hugh Price Hughes, and their alliance was forged in public and private discussions in Switzerland

38 Review of the Churches 4, no 6 (September 1893) 374

39 Revnew of the Churches 4, no 6 (September 1893) 348, also Revnew of the Churches 6, no 32 (May 1894) 67

40 Bebbungton, Nonconfornust Conscuence, 70

41 James S Drummond, Charles A Berry D D A Memorr (London Cassell and Co, 1899), $119-23$ 
in 1892 and $1893 .{ }^{42}$ One can observe the convergence of their thoughts in the records of the conferences. Berry started out, as he later recalled, "only half-convinced" even of the utllity of the Conferences themselves, but was soon converted into "an enthusiastic Re-unıonist." He returned in 1893 boldly to declare his "high-churchmanship" and ended up in 1895 advocating further and more official conferences on doctrine. The effect he had on Hughes was even more apparent. Hughes later revealed that while he had "long avolded the doctrines of the Church, the sacraments, and the ministry," conversations with Berry convinced him "that the only antidote to Anglican schism and Roman heresy [was] the reassertion of the great cardinal doctrines of the Christian Church, the Christian sacraments, and the Christian ministry. ${ }^{\prime 44}$ After Grindelwald, Hughes abandoned his enthusiasm for the union of Methodism with Anglicanism and returned with renewed avidity to building a Nonconformist common front, first by joining Berry in establishing the National Council of Free Churches and then by supervising the formulation of a Free Church catechism With Berry providing the theological formulation and Hughes the vibrant oratory, a new team was formed thit eventually was to organize, promote, and guide the Free Churches in the coming years.

The practical effect of hours of private discussions between Hughes, Berry, and other Nonconformist leaders was apparent both during and after the Conferences. As Lunn recalled, "every point in their plans, which have resulted in the development of so remarkable a work [the National Council of Evangelical Free Churches] was thrashed out in detail between the village of Grindelwald and the surrounding glaciers." ${ }^{\prime 5}$ The first four presidents of the Free Church Council were participants at Grindelwald: Berry, Hughes, the Presbyterian Munro Gibson, and Alexander Mackennal ${ }^{46}$ Mackennal concluded years afterwards that Grindelwald helped reveal and promote among Nonconformists "a growing desire to bring all the spiritual forces of the various churches to bear upon the national life unitedly." ${ }^{7}$ "No one," he recollected, "had any suspicion how broadly

42 Although $D W$ Bebbington recognizes Berry's leadership and that he was reacting to the Grundelwald Conferences, he does not recognize that the important Hughes-Berry partnershıp also took shape at Grindelwald He dates the origm of Hughes and Berry's friendship to 1895-96, about three years too late See Behbington, Nonconformist Conscience, 63,70

43 Drummond, Charles Berru, 104

44 Drummond, Charles Berry, 119 See also E K H Jordan, ltee Church Unity A History of the Free Church Counctl Movement 1896-1941 (London Lutterworth, 1956) 120

45 Quoted in Drummond, Charles Berry, 112

46 Drummond, Charles Berry, 112, D W Bebbington, Nonconformist Conscuence, 63

47 Macfadyen, Alexander Mackennal, 232 
and how deeply such thoughts were working in men's minds until the Review of the Churches was founded and the conferences at Grindelwald and Lucerne were held." ${ }^{48}$ Hughes and Berry followed up their 1893 discussions by orchestrating passage in the 1894 Free Church Congress of a resolution calling for a permanent Free Church federation in which local Free Church councils around the country would elect representatives to a National Council It was to be, Hughes declared, "a real Nonconformist Parliament, which will be able to defend our imperiled interests in town and country, to voice the Nonconformist Conscience and to promote the evangelization of England "49

Although the Free Church Council was now in the makıng, the Grindelwald Conferences continued for two more summers, and neither Hughes nor Berry was yet prepared to abandon discussions with Anglicans. The third year of Reunion Conferences, held again in Grindelwald in August of 1894, had a larger attendance than ever, including a larger contingent of high-church Anglicans. Lunn introduced a number of innovations. He had invited a number of prominent editors to discuss the role of the periodical press in religious life. There was a special session devoted to Methodist reunion, and there was the first public statement issued jointly by the conference. This letter reiterated the call for Whit Sunday intercessions for reunion, urged the creation of ecumenical social unions to coordinate action on social problems, recommended regular conferences throughout Britain "for counc1l and encouragement" and for elimination of overlapping agencies, and finally called for cultivation of a belief that brotherly conferences might overcome differences between Christians and foster a desire for real unity ${ }^{50}$

The Conference of 1894 consisted of two full days of discussions and a third day for various Methodıst denominations Agam, in spite of their more or less liberal interpretation of the episcopacy, Anglican speakers tended to agree that union with Nonconformists was not an immediate prospect and that Nonconformists needed to unify and define themselves first. The Dean of Norwich, William Lefroy, crit1cized the Nonconformists' lack of ecclesiastical discipline within and among their various denominations and their failure to produce a common proposal for reunion with Anglicanısm. ${ }^{51}$ Berry countered

48 Macfadyen, Alexander Mackennal, 232

49 Methodist Times, 22 March 1894, 177

50 Review of the Churches 6, no 36 (September 1894) 374 Two high-church participants, $\mathrm{R}$ M Grier and W S Swayne, dissented from the recommendation of regional conferences on cooperation

51 Reveru of the Churches 6, no 36 (September 1894) 343-44 
by questioning whether the Church of England had itself passed a resolution on reunion. He understood the Quadrilateral to be a condition for discussion rather than a proposal for negotiations. $W S$. Swayne, Vicar of Walsall, an admitted "sacerdotalist," also advised that the Nonconformists close ranks before negotiating with the Church of England. He defended the historic episcopate as a valuable middle ground in Christendom as a whole. R. M Grier, Prebendary of Litchfield, was similarly concerned that an overly liberal interpretation of episcopacy might preclude reunion with Roman Catholicism.

On the second day of discussions, the Dean of Bristol, Francis Pigou, reiterated the call for practical unity of spirit rather than organıc union. Might British Christians, he asked, demonstrate their unity through cooperation in organizations such as the British and Foreign Bible Society and other philanthropic agencies? Charles Berry rejoined by proposing a conference in England of official church representatives to examine the controversial fourth clause of the Lambeth Quadrilateral and thresh out a common doctrine of church and ministry. ${ }^{52}$ Sounding more like Hugh Price Hushes, he declared that he was "more concerned than when he first came to Grindelwald that some agreement on Church and State be reached "

Now, ironically, it was Hughes and Bunting who poured cold water on the idea. Bunting declared that he had come to feel more than he did at first that "unity of faith in Christ, and belief in the cardinal doctrines of the Christian religion, and a mutual recognition of that unity in all manner of ways, was a far more important thing than any amount of organic unity" Hughes was sorry to say that he thought Berry's proposal was "premature." 53 Why this apparent shift in positions? Grindelwald had indeed produced greater clarity on issues of church union. This seems to have inspired in the more theological mind of Berry a desire to hammer out a comnion ecclesiastical doctrine By contrast, this same clarity of view disillusioned Hughes. He had come to see that most participants at Grindelwald did not concur with his instrumental definition of the church and that no amount of doctrinal debate about ministry and episcopary would change that fact. He blamed St Augustine for introducing what he thought was a profound confusion of the concepts of the kingdom and church $\mathrm{He}$ had not been able to convince the conference that the church was merely an instrument for creating the kingdom and that unity was not a doctrinal matter at all, but a matter of effectiveness He proposed that instead of a conference on doctrine, there should be a permanent

52 Revew of the Churches 6, no 36 (September 1894) 364

53 Rentew of the Churches 6, no 36 (September 1894) 371) 
society formed to promote the idea of unity. It was also clear from his remarks that he focused his immediate hope on the convergence of Nonconformity and on the hope that the new Free Church Council that he and Berry were organizing would be the first step in demonstrating his concept of the church.

In reviewing the 1894 Conference, William Sinclair, the Archdeacon of London who was the new Anglican editor for the Review of the Churches, insisted that Hughes's continued support for the episcopacy "marks an epoch in the question of Reunion" Sinclair was quite enthusiastic about the prospect of the convergence of Methodism and Anglicanism. Bunting, as Methodıst editor, was hopeful that the high-church Anglicans were impressed by Nonconformist support for a "true Apostolical succession, residing not in a succession of officers, but in a succession of the whole mass of believers." He noted the irony that many Free Church leaders (notably Hughes and Berry) had sided more with high-church Anglicans on the importance of the visible church and organic unity than with evangelical Anglicans, such as Webb-Peploe, who emphasized the spiritual nature of the church. By contrast, however, the Congregationalist editor, Alexander Mackennal, was pleased with the Conference precisely because enthusiasm for a general scheme of Protestant reunion had been abandoned. $\mathrm{He}$, like Hughes, was convinced that Free Church union was the most promising prospect, even though he thought further discussions with Anglicans could take place if the fourth clause of the Quadrilateral (concerning the episcopacy) "might be regarded as open to discussion and amendment." 55

The emerging consensus of the Grindelwald participants, indeed, was that there was little more to be done through Swiss conversations. There was one final and rather small conference at Grindelwald in 1895, but no new ground was broken. The Archdeacon of Manchester, James Maurice Wilson, hoped to inspire a new direction by suggesting that Nonconformists be made orders within the Church of England, a proposal that failed to 1mpress the Free Church particlpants. ${ }^{56}$ Instead, Berry reiterated his call for a conference in England on church and ministry, also to little effect. Hughes was now convinced that the Establishment would not "recognize the preponderance of the Nonconformists" until they had united themselves. He faulted the Church of England for exaggerating their own importance, for relying upon the political establishment of their church, and for

54 Revtew of the Churches 6, no 36 (September 1894) 328

55 Macfadyen, Alexander Mackennal, 234

56 Review of the Churches 6, no 41 (October 1895) 311-13 
having a "sacerdotal spirit" regarding apostolic succession. The Grindelwald experiment was clearly played out. The circulation of the Reviezt of the Churches had likewise suffered a decline, and Lunn had been forced to reduce it to a quarterly in October 1894. Publication ceased in the spring of 1896.

After the final Grindelwald Conference in 1895, Hughes and Berry spent several months touring the country promoting the Free Church Council. In March 1896 at Nottingham, the fourth Free Church Congress met, made up of representatıves of 209 local Free Church counclls, most of which had been formed in the previous two years. The Congress adopted a new constitution and a new' title devised by Berry to suggest its theological position as well as its permanence: "The National Council of the Evangelical Free Churches." The new constitution established an elected Executive Committee made up of equal numbers of ministers and laymen and an elected President of the Council who served for a year's term. Hughe, was elected the first president, and in his presidential address he emphasized that the Free Church Council was to pursue four objects: the fraternal association among the Free Churches, the deepening of spiritual life, the evangelization of the unreached masses, and the exposition of the true doctrine of the church This last object, the one that had evolved in his mind at Grindelwald, was the critical one for Hughes "It is high tıme," he declared, echoing Berry's Grindelwalı declaration, "that we made a more positive statement of our Faith. What are we? We are Free Evangelical Churchmen. Above all, we are Churchmen." The Roman Catholic, he averred, "stands for the supremacy of the Pope, the Anglican Catholic for the supremacy of the Crown, and the Scriptural Catholic for the supremacy of the Christ." The effective unity of the Free Churches would, he thought, place "the future of British Christranity and of the British Empire in our hands. In the most important and influential quarters of the civilised globe we can, under God, build up a Holy, Catholic, and Apostolı Church; we can decisively influence the course of human events; we can greatly hasten the advent of the blissful day "when the world shall have become the kingdom of the Christ." " 57 Having falled to reunite with the established church, Hughes and Berry sought to build a new national, indeed international, Free Church without them.

\section{Grindelwald in the History of Ecumenism}

The Grindelwald Conferences have passed into historical oblivion because they failed to perpetuate themselves institutionally Even the 
intellectual connection that Rouse attempted to establish between Grindelwald and Edinburgh in 1910 evaporates on closer inspection. Grindelwald anticipated, rather than precipitated, the Faith and Order movement in the twentieth century. In the final analysis it farled, as Alexander Mackennal recognized at the time, to capture the imagination of the British public. On the other hand, Grindelwald merits a place in the history of English Christianity It was the first manifestation of a new ecumenical spirit fired by the emerging ideals of a liberal social gospel, particularly of the Methodist Forward Movement. The most concrete result of the conferences was the advent of the National Council of Evangelical Free Churches, with the express charge to develop a new, broadly evangelical ecclesiology, which found expression in the Free Church Catechism, which was widely used in Sunday schools and Free Church home missions before the war. ${ }^{58} \mathrm{~A}$ second and perhaps more important result of the Grindelwald Conferences was a new awareness and understanding of the issues that divided English churches. As such, they represented the awkward first steps in a century of subsequent ecumenical efforts in England.

Some recent historians have lamented Grindelwald's first product, the formation of the Free Church Council, as a great historical wrong turn. Whether that is true or not, these historians' inattention to the events at Grindelwald has contributed to a number of misunderstandings about this event and Nonconformist history more generally. John Kent contends that Hugh Price Hughes's efforts to bring Methodism into the Nonconformist camp betrayed Methodism's true Anglican nature. Hughes, Kent believes, "did not entirely understand the past of Wesleyan Methodism," (namely its roots in Anglicanism) and in bringing Methodism into closer association with other Nonconformists, "almost succeeded in changing what he found out of all recognition. ${ }^{\prime 59}$ The irony of Kent's critique is that the very man he blamed for driving Methodısm away from Anglicanism was also the only Methodist leader of the nineteenth century who actively sought to unite Methodısm and Anglicanısm His inability to do so at the Grindelwald Conferences was confirmation that the Methodist future lay with the Free Churches

Richard J. Helmstadter also contends that Free Church unity was a wrong turn, though in a sense almost diametrically opposed to Kent's. Helmstadter argues that Methodists and other Nonconformists had

58 John Munsey Turner, Confluct and Reconctlation Studies in Methodism and Ecumenism in England, 1740-1982 (London Epworth, 1985), 175

59 John Kent, The Age of Disunity (London Epworth, 1966), 200 
established a "cohesive culture" in the mid-Victorian period based upon a common evangelical theology and a social emphasis on sturdy individualism. That consensus began unraveling in the 1880 s and $1890 \mathrm{~s}$, and the ecumenism of Lunn, Hughes, and Berry was a part of this unraveling. In his view, the effects of "fashionable new ideas," such as incarnationalist theology ("a religion of weakness"), which undermined evangelicalism, and an inchoate socialism, which destroyed the ethic of individualism, rendered Nonconformists confused and vulnerable. This, in turn, prompted discussions about unifying the Free Churches and Protestants generally ${ }^{60}$ A weakness of Helmstadter's interpretation is the failure to account for the logic of ecumenism apparent in the Grindelwald discussions. The Grindelwald Conferences were inspired by a sense of evangelical urgency, not by its absence. In contrast to what Helnsstadter suggests, the collapse of evangelicalism and related social gospel movements in England in the twentieth century undermined rather than strengthened the ecumenical impulse Helmstadter's attempt to present ecumenism as the opposite of evangelicalism does not adequately describe the thought of this period.

The dream of a united Free Church and a united Protestantism, first embraced at Grindelwald, has been pursued intermittently throughout the twentieth century in parallel with the worldwide Farth and Order Movement. As Grindelwald partıcipants anticipated, greater Nonconformist unity helped stimulate further dialogue with the Church of England In 1920, the Lambeth Conference of Anglican bishops, responding to the sobering and unifying experience of World War I and to the gathering momentum of the Falth and Order Movement, issued a statement entitled "An Appeal to all Christian People," which formally acknowledged the validity of nonepiscopal minustry as "effective means of grace. ${ }^{\prime 61}$ In 1921, the Free Churches, acting in concert through their federal bodies, arranged a conference with the two Anglican archbishops and other Church of England leaders about the nature of the church, ministry, and creed Here, finally, was the

60 Richard J Helmstadter, "The Nonconformist Conscience," chapter in Religion $m$ Victorian Britain, Vol 4 of Interpretations, ed Gerald Parsons (Manchester Manchester University Press, 1988), 82-95

61 For a discussion of the circumstances and consequences of the Appeal fo All Christian Prople 1ssued by the 1920 Lambeth Conference of Bishop, see Adrian Hastıngs, History of English Christianty, 1920-1990, 3d ed (London SCM Press, 1991), 97-99 See also Sidney Dark, The lambeth Conferences Their History and ignificance (London Eyre and Spottiswoode, 1930), 131-42, and also the introduction to the Archbishop of York, W' B Shelbie, J Scott Lidgett, P Carnegre Simpson, the Bishop of Gloucester, and J G Simpson, The Lambeth Joint Report on Church Unty A Di cussion (London Hodder and Stoughton, 1923) 
ecclesiastical conference proposed by Charles Berry almost thirty years before. Several months of meetings in 1922 at Lambeth Palace produced the Report of the Joint Lambeth Committee, whose key resolutions followed the lines recommended by the Bishop of Worcester and Hugh Price Hughes at Grindelwald. The episcopacy was accepted as the primary authority in the future united English church, but not the doctrine of apostolic succession. The ministry of the Free Churches was accepted as valid, and the power of bishops was to be constrained by the authority of congregations. ${ }^{62}$

Henry Lunn was inspired by these developments to renew his ecumenical efforts. He organized two more Swiss conferences in 1923 and 1924 at his ski resort at Müren on church cooperation in social reform and issued a new series of the Review of the Churches. Denominational responses to the Jount Report indicated, however, that serious differences remained. ${ }^{63}$ An Anglican memorandum of 1925 made clear that recognition of the efficacy of Free Church orders did not necessarily mean they were understood to have the same authority as those ordained by the episcopacy. The Free Churches still refused any concession on reordination. In the 1920s, as in the 1890s, most British churchgoers were unconvinced of the need for greater unity. AngloCatholics, led by Bishop Gore, strongly resisted concessions on the creeds or episcopacy. Enthusiasm for unity with Anglicanism expressed by Methodist John Scott Lidgett, Congregatıonalıst W. B. Selbie, and Baptist J. H. Shakespeare-the direct successors in their respective denominations of the leaders at Grindelwald-was still not embraced by the rank and file of Nonconformity. ${ }^{64}$ Ecclesiastical conservatism and a lack of evangelical urgency made the ideal of reunion unattainable. There was less conservatism, however, and more urgency in the commonwealth. In India, the 1922 Lambeth Joint Report and subsequent discussions set the stage for the establishment of the Church of South India in 1947, a merger of Anglicans with Methodists, Congregationalists, and Presbyterians that was the first union of episcopal and nonepiscopal churches since the Reformation. In England, it was not until 1969 that a plan to unite Methodists and Anglicans was hammered out, yet it fell short of a sufficient majority in Church of England assemblies. Discussions between these two churches have continued on and off ever since. In 1972 English Presbyterians and Congregationalists merged to form the United

62 The Lambeth Joint Report on Church Unity A Discussion, 155-56

63 Turner, Conflict and Reconcilation, 185-89

64 Ernest A Payne, The Free Church Tradtion in the Life of England, 3d ed (London SCM Press, 1951), 160-64, see also Turner, Conflict and Reconchlation, 176-77, 190-91 
Reformed Church, the only union of major Protestant denominations achieved thus far.

These developments indicate that the ideals expressed and issues debated at Grindelwald have not yet played themselves out. The problems remain stubbornly familiar, though perhaps the motivations for union have changed and in some ways diminished. The millennial expectancy of both evangelical trumph and social redemption that first ignited modern ecumenical enthusiasm is a bygone feature of Anglo-American Protestantism-especially Methodism-at the turn of the last century. 